*УДК 342.25

Дорош В.Ю., к.е.н, доцент

Камінська I.М., к.е.н, доцент

Янчук Я.А.

Луцький національний технічний університет

\title{
СОЦІАЛЬНИЙ ВЕКТОР ФІНАНСОВОЇ СПРОМОЖНОСТІ ОРГАНІВ МІСЦЕВОГО САМОВРЯДУВАННЯ
}

Стаття присвячена вивченню теоретичних засад та практичних аспектів бюджетного забезпечення соціальної сфери. Проведено діагностичний моніторинг виконання видатків соціально-культурної сфери зведеного бюджету Волинської області, запропоновано заходи наповнення місцевих бюджетів.

Ключові слова: бюджет, бюджетний процес, видатки бюджету, соціальна сфера

\section{Dorosh V., Kaminska I., Yanchuk J. \\ SOCIAL VECTOR OF FINANCIAL CAPACITY OF LOCAL AUTHORITIES}

The article is devoted to the study of theoretical foundations and practical aspects of budgetary provision of social sphere. One of the convincing conditions for the establishment of a socially oriented state is the ability of local governments to ensure the sustainable development of territories, and this becomes possible in the presence of an effective budget policy in general and the budget process in particular. This issue is particularly acute in the process of financing socio-cultural expenditures, which directly depends on the socio-economic situation of the country, its regions and ordinary citizens.

Diagnostic monitoring of the expenditures of the socio-cultural sphere of the consolidated budget of Volyn region has been carried out. Social expenditures of local budgets are a significant factor in socio-economic development. In modern conditions, they serve as a key source for ensuring the vital needs of citizens. It depends on the level of implementation and effective use of local budget expenditures that depend on the socio-economic development of the region and the country as a whole.

Measures to fill local budgets are proposed. In Ukraine, unlike the leading countries of the world, at the moment there is not enough cooperation with the non-governmental sector, with charitable and religious organizations. Therefore, the main burden lies on budgets of different levels. In our opinion, the priority in the process of the domestic system of social services is the denationalization of the social sphere. This will be possible through the decentralization of social services, the detailed selection of service providers of all forms of ownership, the involvement of public, private and charitable organizations on a competitive basis. This will

* Дорош В.Ю., Камінська I.М., Янчук Я.А. 
reduce the inequality of citizens in accessing social, medical, educational and other services, their territorial approximation to the place of residence of a person.

Key words: budget, budget process, budget expenditures, social sphere.

\section{Дорош В.Ю., Каминская И.Н., Янчук Я.А.}

\section{СОЦИАЛЬНЫЙ ВЕКТОР ФИНАНСОВОЙ СОСТОЯТЕЛЬНОС- ТИ ОРГАНОВ МЕСТНОГО САМОУПРАВЛЕНИЯ}

Статья посвящена изучению теоретических основ и практических аспектов бюджетного обеспечения социальной сферы. Проведен диагностический мониторинг исполнения расходов социально-культурной сферы сводного бюджета Волынской области, предложены меры наполнения местных бюджетов.

Ключевые слова: бюджет, бюджетный процесс, расходы бюджета, социальная сфера.

\section{Постановка проблеми у загальному вигляді та її зв'язок 3} важливими науковими та практичними завданнями. Однією 3 переконливих умов становлення соціально орієнтованої держави $є$ спроможність органів місцевого самоврядування забезпечувати сталий розвиток територій, а це стає можливим при наявності ефективної бюджетної політики в цілому та бюджетного процесу зокрема. Особливо гостро це питання постає у процесі фінансування соціально-культурних видатків, від яких напряму залежить соціально-економічне становище країни, їі регіонів та простих громадян.

Аналіз останніх досліджень, у яких започатковано вирішення проблеми. Вагомий внесок у розробку теоретичних та методичних засад оцінки проблеми формування та виконання місцевих бюджетів внесли вчені-економісти: С. Юрій, Л. Алексеєнко, І. Зятковський, Н. Пігуль, О. Люта, А. Бойко, В. Горин, О. Романенко, В. Опарін, С. Мочерний, А. Сидорчук, М. Ходорович, В. Швець, В. Дем'янишин, І. Сидор та ін.

Цілі статті полягають у дослідженні практичних аспектів бюджетного забезпечення соціальної сфери.

Виклад основного матеріалу дослідження з повним обгрунтуванням отриманих наукових результатів. Видатки бюджету будьякого рівня представляють собою важливу складу формування сталого розвитку держави. Особливо болючим питанням останніх років є витрати місцевих бюджетів соціально-культурного спрямування, які по 
суті є тим індикатором, що визначає рівень соціального розвитку країни.

Основою для проведення дослідження слугують аналітичні дані департаменту фінансів Волинської ОДА [1].

Отже, як видно з рис. 1 найбільшу питому вагу у видатках місцевих бюджетів України займають видатки соціально-культурного спрямування. Зокрема, частка витрат на соціальний захист та соціальне забезпечення у загальних витратах складає $54 \%$, витрати на освіту $-24 \%$, на охорону здоров'я - $12 \%$. Іншим витратам належить близько $10 \%$ в структурі місцевих бюджетів України. У нинішніх умовах питома вага видатків соціально культурного спрямування підтверджує соціальну спрямованість обласного бюджету Волинської області.

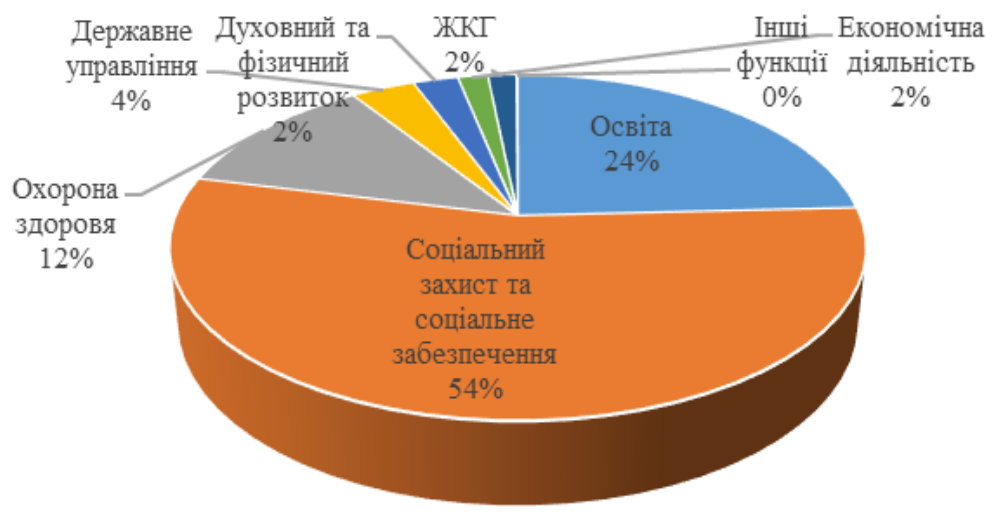

Рис. 1. Структура видатків місцевих бюджетів України

Так, частка коштів, яка виділялася на фінансування цільових програм у сфері соціального захисту, охорони здоров'я та освіти $є$ найбільшою. Питома вага видатків соціального спрямування на кінець 2017 року склала 91,9\% зведеного бюджету Волинської області.

Таким чином, на підставі дослідження частки соціальних витрат зведеного бюджету Волинської області можна зазначити, що витрати соціальної спрямованості займають значну питому вагу у загальних витратах бюджету. Наявні тенденції свідчать про збереження структур- 
них пропорцій між складовими бюджетних витрат впродовж досліджуваного періоду.

Протягом 2014-2017 рр. найбільш вагомими в структурі залишалися видатки на соціальний захист та освіту. Так, у 2017 році видатки на соціальний захист склали $43,01 \%$ та освіту $-36,08 \%$. Незмінною лишається частка витрат на культуру і мистецтво, яка протягом досліджуваного періоду не перевищує 4\%. Дані таблиці свідчать, що видатки на фізичну культуру і спорт займають незначну частку та складають в середньому $0,8 \%$.

Оцінка динаміки видатки місцевих бюджетів Волинської області у 2014-2017 pp. за соціально-культурним спрямуванням говорить про те, що за усіма статтями видатків відбувався ріст. У 2017 р. в порівнянні 32016 р. найбільший приріст витрат спостерігався за статтею освіта $(16,06 \%)$. Видатки на охорону здоров'я зросли на $6,44 \%$, соціальний захист - 2,26\%, культуру і мистецтво - 8,69\%, фізичну культуру і спорт - 6,41\%. За 2017 рік на фінансування галузей соціально-культурної сфери із загального фонду обласного бюджету спрямовано 1371,0 млн грн або 96 відсотків усіх видатків загального фонду, що становить 96,8 відсотка до запланованого на рік. На фінансування установ та закладів освіти спрямовано 575,2 млн грн (що більше на 185,9 млн грн порівняно з 2016 роком), охорони здоров'я - 631,0 млн грн (+169,8 млн грн), соціального захисту населення - 65,7 млн грн (+20,4 млн грн), культури і мистецтва - 69,5 млн грн (+20,2 млн грн), фізичної культури і спорту 29,6 млн грн (+7,9 млн гривень). В цілому на фінансування вищезгаданих галузей за 2017 рік спрямовано на 404,2 млн грн більше порівняно 3 2016 роком.

Результати дослідження дають можливість говорити, що суттєвої зміни видатків місцевих бюджетів не відбулося. Основними напрямами фінансування залишаються видатки на соціальний захист на соціальне забезпечення, освіту, охорону здоров'я.

Видатки соціальної сфери місцевих бюджетів - це вагомий чинник соціально-економічного розвитку. В сучасних умовах вони виступають ключовим джерелом забезпечення життєвих потреб громадян. Саме від рівня виконання та ефективного використання видатків місцевих бюджетів залежить соціально-економічний розвиток регіону та країни в цілому. Розглянемо виконання видатків місцевих бюджетів Волинської області по галузях соціально культурної сфери (рис. 2). 
Як бачимо з діаграми видатки місцевих бюджетів Волинської області по галузях соціально культурної сфери у загальному підсумку 2017 року не виконані: соціальний захист на 1,3\%, охорона здоров'я та фізична культура і спорт на 1,6\%, культура та мистецтво на 1,9\%, освіта на 2,9\%. У 2017 році зведений бюджет області за функцією освіта був недовиконаний всіма районами області $(97,6 \%)$, обласним бюджетом (94,7\%), містами обласного значення (98,3\%) та об'єднаними територіальними громадами (94,5\%). Схожа ситуація притаманна іншим видаткам соціально-культурного спрямування зведеного бюджету Волинської області. Зокрема видатки по охороні здоров'я недовиконані всіма районами області (1,8\%), обласним бюджетом (1,9\%), містами обласного значення $(1,1 \%)$ та об'єднаними територіальними громадами $(1,6 \%)$.
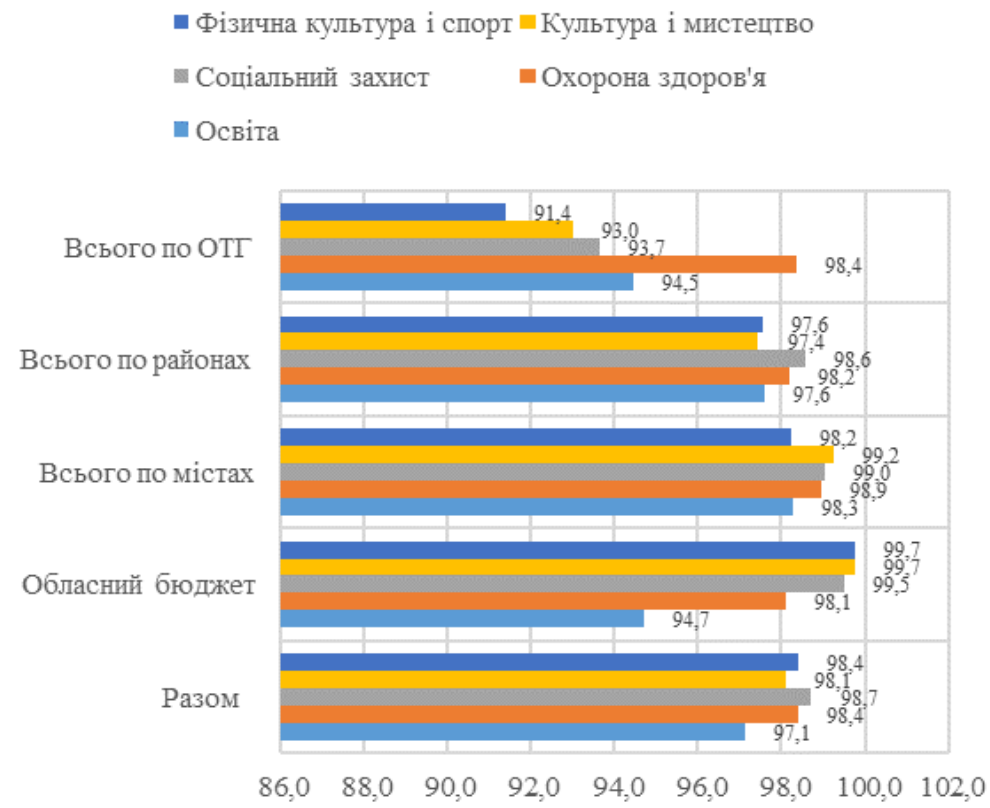

Рис. 2. Виконання видатків місцевих бюджетів Волинської області по галузях соціально культурної сфери, \%

Найкращою виконавчою дисципліною фінансування планових видатків на соціальний захист характеризується обласний бюджет. Рі- 
вень його виконання 99,5\%, найнижчим ОТГ - 93,7\%. Так ж ситуація у сфері видатків на культуру і мистецтво. Рівень виконання ОТГ 93,7\% (найнижчий), обласним бюджетом 99,7\% (найвищий).

Що стосується видатків на фізичну культуру та спорт, то рівень виконання був наступним: ОТГ - 91,4\%, райони - 97,6\%, міста обласного значення - 98,2\%, обласний бюджет - 99,7\%.

Висновки. В Україні, на відміну від провідних країн світу, на разі недостатньо напрацьована співпраця 3 недержавним сектором, iз благодійними та релігійними організаціями. Тому основне навантаження лежить на бюджетах різних рівнів.

На нашу думку, пріоритетом у процесі вітчизняної системи соціальних послуг є роздержавлення соціальної сфери. Це стане можливим через децентралізацію соціальних послуг, детальний підбір постачальників послуг усіх форм власності, залучення громадських, приватних i благодійних організацій на конкурсних засадах. Що забезпечить зменшення нерівності громадян у доступі до соціальних, медичних, освітніх та інших служб, їх територіальне наближення до місця проживання людини.

1. Зведені бюджети Волинської області за 2014-2017 pp. - [Електронний ресурс]. Режим доступу: http://www.finance.voladm.gov.ua/.

*УДК 657.9.517

Голячук Н.В., к.е.н., доцент

Голячук С.С., к.с.-г.н., доцент

Луцький національний технічний університет

\section{АНАЛІЗ ФІНАНСОВОГО СТАНУ ЛІСОГОСПОДАРСЬКИХ ПІДПРИЕМСТВ 3 ВИКОРИСТАННЯМ БАЛЬНОЇ ОЦІНКИ}

У статті розраховані показники фінансового стану лісогосподарських підприємств, проведена їх інтегральна оцінка.

Ключові слова: лісове господарство, підприємство, фінансовий стан, фінансова звітність.

* Голячук Н.В., Голячук С.С. 